\title{
Lärande för hållbar utveckling i yrkeslärarutbildning
}

\author{
(Learning for sustainable development \\ in vocational teacher education)
}

\section{Susanne Gustavsson, Ingrid Henning Loeb, Charlotta Kvarnemo}

Göteborgs Universitet, Sverige (ingrid.henning-loeb@ped.gu.se)

\begin{abstract}
This article draws on data from a module on education for sustainable development (ESD) in vocational teacher education. There are two kinds of data: 47 group work projects, where the assignment was to design an ESD activity in upper secondary vocational education, and a web questionnaire (average response rate of $80 \%$ ). The purpose is to describe and discuss how ESD can take form in vocational teacher education, and how the students value the knowledge that they have acquired when working with the module. The results give a positive picture of many different pedagogical approaches of planning an ESD activity. The variety of the contents of the activities stretch from having specific vocational focus, to broader societal perspectives. The planned activities for the pupils also differ, from participating in classroom exercises to activities based on actionand student-based planning. The different pedagogical approaches are exemplified and discussed. The results from the questionnaire show that over all, the students are positive to the content of the ESD module and the work that is carried out within this part of the course. These results are related to previous studies with critical aspects of teaching ESD.
\end{abstract}

Keywords: vocational teacher education, learning for sustainable development, vocational education and training, pedagogy, student projects

NJVET, Vol. 8, No. 3, 19-35 Peer-reviewed article doi: 10.3384/njvet.2242-458X.188319 


\section{Inledning}

Begreppen hållbar utveckling och lärande för hållbar utveckling är numer vanligt förekommande i utbildningars måldokument. 2006 fastställdes i den svenska högskolelagen att universitet och högskolor ska främja en hållbar utveckling för nuvarande och kommande generationer (SFS 1992:1434, 1 kap. 5 §). Detta krav associerar både till universitets och högskolors utbildningsmiljö samt till innehåll och mål i program och kurser. Begreppen återfinns även i de nationella examensmålen. Enligt mål för yrkeslärarexamen ska studenten "visa förmåga att i det pedagogiska arbetet göra bedömningar utifrån relevanta vetenskapliga, samhälleliga och etiska aspekter med särskilt beaktande av de mänskliga rättigheterna, i synnerhet barnets rättigheter enligt barnkonventionen, samt en hållbar utveckling" (SFS 1993:100, bilaga 2). Begreppet hållbar utveckling uttrycks således explicit i ett examensmål, vilket föranleder att det både ska behandlas i undervisningen och examineras. Skrivningar i läroplaner och olika programmål i gymnasial yrkesutbildning visar också att yrkeslärare måste kunna förhålla sig till begreppet i sin undervisningskontext, både i en allmän och en yrkesspecifik betydelse. I vilket sammanhang och hur begreppet ska behandlas i yrkeslärarutbildningen är dock inte självklart. Den svenska lärarutbildningen är decentraliserad och hur undervisningen och examinationen av de olika examensmålen ska genomföras är upp till de enskilda lärosätena (eller mer specifikt den för kursen ansvariga institutionen) att bestämma.

Denna artikel grundar sig på ett moment som fokuserar på hållbar utveckling $i$ en av kurserna i Yrkeslärarprogrammet vid Göteborgs universitet. Utbildningsformen är halvfart och i hög grad distansburen, dock med en eller flera campusförlagda utbildningsdagar. Momentet om hållbar utveckling har tagits fram i ett samarbete mellan lärare vid utbildningsvetenskaplig fakultet och lärare vid naturvetenskaplig fakultet och omfattar motsvarande 2 högskolepoäng (hp) av kursens $7,5 \mathrm{hp} .{ }^{1}$ I momentet ingår en inledande föreläsning om hållbar utveckling, litteraturstudier, ett grupparbete samt en individuell reflektion som komplement till grupparbetet. Grupparbetet är didaktiskt orienterat, där studenterna tar fram ett förslag på hur hållbar utveckling kan behandlas i yrkesprogram. Studenterna arbetar i grupper fram det konkreta innehållet och formen för det tänkta undervisningsupplägget, vilket presenteras vid kursens avslutande campusförlagda dag. Sammanlagt har 47 projektredovisningar genomförts sedan 2013. Det är dessa projektredovisningar och kursutvärderingar av momentet som ligger till grund för denna artikel.

Artikeln har två syften: dels att belysa och diskutera hur lärande för hållbar utveckling kan ta sig i uttryck i Yrkeslärarprogrammet, dels att belysa och diskutera hur studenterna värderar det lärande och den kunskap som de erhållit genom momentet. 


\section{Lärande för hållbar utveckling i policy och forskning}

Lärande för hållbar utveckling (Education for Sustainable Development) är ett tämligen nytt forsknings- och utbildningsfält. Fältet har vuxit fram samtidigt som policyområdet befästs. Startskottet tillskrivs oftast rapporten från den så kallade Brundtlandkommissionen (WCED, 1987) som FN tillsatte i mitten av 1980-talet, med uppdraget att utarbeta förslag till långsiktiga miljöstrategier för en hållbar utveckling. Brundtlandskommissionens definition av hållbar utveckling innebär en utveckling som tillfredsställer dagens behov utan att äventyra kommande generationers möjligheter att tillfredsställa sina behov. Kommissionen betonade en holistisk syn utifrån tre integrerade perspektiv: ekonomiska, miljömässiga och sociala. Förenta Nationernas årtionde för lärande om hållbar utveckling, den så kallade "Dekaden" (Unesco, 2014), utgjorde avstampet för utbildningsinstitutioners och skolors arbete med temat. Vid denna tid formades också forskningsfältet. Det kan exemplifieras med två tidskrifter: första numret av International Journal of Sustainability in Higher Education utkom 2000, och Journal of Education for Sustainable Development publicerades första gången 2007. Såväl policy om hållbar utveckling, exempelvis UNESCO:s Global Action Programme (UNESCO, 2014), som forskningsfältet har under det senaste decenniet alltmer kommit att betona att hållbar utveckling innefattar ett transformativt perspektiv på lärande (Holmberg, Lundqvist, Svanström, Gröndahl \& Arehag, 2012; Lotz-Sisitka, Wals, Kronlid \& McGarry, 2015; Sterling, 2009, Wals, 2011), vilket kan förstås som ett i grunden förändrat synsätt och en handlingsaspekt (Christie, Carey, Robertson \& Grainger, 2015; Mezirow, 1997, 2009). Här finns en skala av olika tolkningar och innebörder.

Wals (2011) beskriver transformativt lärande inom hållbar utveckling som en förening mellan innehåll, personlig utveckling och kollaborativ kompetens. Andra betonar att transformativt lärande är kopplat till bildning (Mogensen \& Schnack, 2010), och till ett kritiskt förhållningssätt (Garrison, Östman \& Håkansson, 2014; Sund \& Wickman, 2011; Thomas, 2009). Det finns exempel på studier, som visar att temat påverkar elevers medvetenhet inom området (Boeve de Pauw, Gericke, Olsson \& Berglund, 2015), samtidigt som det holistiska perspektivet inte verkar få genomslag (Olsson, Gericke, \& Chang Rundgren, 2016). Elevers möjlighet att utveckla ett kritiskt förhållningssätt och att ifrågasätta normer problematiseras (Öhman \& Öhman, 2012).

En annan tematik i forskningsfältet är lärares kunskaper om området och de undervisningsformer som lärande för hållbar utveckling förväntas inbegripa, vilket innefattar didaktikens vad-aspekt och hur-aspekt. När det gäller didaktikens vad-aspekt visar resultatet av en enkätstudie med 3229 svenska gymnasielärare (Borg, Gericke, Höglund \& Bergman, 2014) att det ekologiska perspektivet dominerar lärares uppfattningar av vad begreppet står för och den undervisning som 
eleverna erbjuds. I en svensk intervjustudie med 17 lärare som undervisar om hållbar utveckling (Björneloo, 2007) framkommer dock en rikare resultatbild. Där riktas undervisning om hållbar utveckling mot helheter och sammanhang, vilket, till skillnad från hos Borg m.fl. (2014) innebär ett holistiskt perspektiv, dvs. att även frågor om social och ekonomiskt hållbar utveckling inbegrips. När det gäller undervisningens utformning är delaktighet och ansvar i fokus. Denna huraspekt innebär en handlingskompetens, att elever ser att de kan göra medvetna val och förstår hur de egna handlingarna påverkar såväl ekonomisk, social som ekologisk hållbarhet. I internationella studier om lärande för hållbar utveckling lyfts kollaborativa, utmanande och reflekterande undervisningsmetoder och arbetsformer fram (Lenglet, Zinaida \& Yoko, 2010; Sterling, 2010a, b; Thomas, 2009; Warner \& Elser, 2015).

Grupparbetena som ligger som underlag för denna artikel har genomförts av yrkeslärarstudenter inom skilda yrkesämnen, dvs. studentgrupperna har varit heterogena avseende yrkesområde. Deras presentationer med förslag på hur hållbar utveckling kan behandlas i yrkesutbildning har gett oss möjlighet att analysera tänkta undervisnings- och lärandeinnehåll, dvs. aspekter av didaktikens vad-fråga. De tänkta undervisningsmomenten har också haft olika utformning och inneburit olika handlingsmöjligheter för elever. På så sätt har vi också kunnat analysera olika utfall som grundar sig i didaktikens hur-fråga.

I kursutvärderingen har tre frågor ställts om momentet om hållbar utveckling. Dels två frågor om i vilken grad studenterna anser att de har uppnått kursmålen för momentet, dels hur de värderar det lärande som momentet har möjliggjort. Detta underlag har gett oss möjlighet att diskutera hur yrkeslärarstudenter värderar det lärande och den kunskap som de erhållit genom momentet. I den avslutande delen av artikeln diskuterar vi också dessa resultat kopplat till anspråken om transformativt lärande inom ovan redogjorda forskning om lärande för hållbar utveckling.

\section{Studentgruppen och utbildningens studiegång}

Studentgruppen kännetecknas av en variation av ålder, kön, yrkesbakgrund och utbildningsbakgrund. Inför antagning till yrkeslärarutbildning görs en bedömning av vilket eller vilka yrkesämnen som den sökande vid utbildningens slut ska få behörighet att undervisa i. Dessa yrkesämnen är knutna till ett eller flera yrkesprogram eller yrkesutbildningar. Yrkesämnena utgör det ämnesdidaktiska fokus som varje yrkeslärarstudent ska förhålla sig till i lärarutbildningen. Före den aktuella kursens start har studenterna genomfört hälften $(15 \mathrm{hp})$ av den verk- 
samhetsförlagda utbildningen, vilket innebär en god kännedom om yrkesutbildning. Drygt hälften av studenterna har under utbildningen tjänst som obehöriga yrkeslärare.

\section{Studiens genomförande}

Studiens empiriska material består av två delar från ett kursmoment som har genomförts varje termin från höstterminen 2013 till och med höstterminen 2017, dvs. sammanlagt nio gånger. Det empiriska materialet består av 47 projektredovisningar och 209 enkätsvar (82 \% av 255 studenter). Projektredovisningarna är det examinerande momentet av ett grupparbete. Instruktionen till gruppuppgiften är följande:

Ta fram ett förslag på hur hållbar utveckling kan behandlas på ett yrkesprogram. Exemplifiera hur miljö- och hållbarhetsfrågor integrerats i verksamheten i form av styrdokument, arbetsbeskrivningar, kunderbjudanden $\mathrm{mm}$. Inspiration kan ni få frăn exempel på tidigare grupparbeten från Yrkeslärarprogrammet. Här är länk: [xxx] Litteraturtips mm finns på [xxx]

Det står er fritt att välja form för ert undervisningsförslag i uppgiften. Ni kan använda bildspel, göra en film, en Facebook-grupp, arbeta i Prezi, storyboard, poster, flyer, kursmaterialskoncept, teaterpjäs. Endast fantasin sätter gränser! Ni behöver inte ha ett färdigt material att presentera på redovisningsdagen, men ni ska kunna redogöra för en plan enligt frågeställningarna nedan.

Gör en plan för ett sådant tänkt projekt:

Vad ingår?

Vilka undervisningsmål har gruppen för undervisningsinslaget?

Vilka perspektiv är i fokus?

Hur kan man få med alla tre perspektiven av hållbar utveckling?

Hur kan projektet knytas till ämnesplaner och kurser?

Vad ser ni som utmaningen med ert projekt?

Hur ser utvecklingspotentialen ut för ert projekt?

Projektredovisningarna som ligger till grund för analysen i denna artikel har hämtats från den lärplattform där studenterna laddat upp sina arbeten. Förutom presentationsmaterialet finns i vissa fall även en kompletterande manustext eller sammanfattning. Analysen av hur lärande för hållbar utveckling kommer till uttryck i studenternas projekt har genomförts med hjälp av kvalitativ innehållsanalys (Graneheim \& Lundman, 2004). Analysen var induktiv och texterna analyserades via begreppen meningsbärande enheter, meningskondensering, kodning, kategorisering och tematisering. Det första steget $i$ analysprocessen innebar att via meningsbärande enheter, meningskondensering och kodning stegvis koncentrera empirin för att identifiera, synliggöra och benämna olikheter och likheter. Data i form av projektpresentationer, manus eller kompletterande texter bearbetades med fokus på de didaktiska frågorna vad och hur. Nästa steg i ana- 
lysen innebar att ordna i kategorier och att tematisera genom att benämna identifierade kategorier. Avslutningsvis gjorde en kvantitativ analys av identifierade kategorier. Resultatet konstruerades i form av en tabell som redovisar teman och frekvens. Den andra delen av studien bygger på kursutvärderingarna, där tre frågor från dessa enkäter har använts för att besvara hur studenterna värderar det lärande och den kunskap som de erhållit genom momentet.

Studenterna har informerats om, och har gett sitt godkännande till, att deras projektredovisningar kan bli föremål för forskning. Studiens resultat presenteras i två delar, med utgångspunkt i studiens tudelade syfte. Först beskrivs hur lärande för hållbar utveckling tar sig i uttryck i projektredovisningarna. Därefter redogörs för hur studenterna värderar det lärande och den kunskap som de getts möjlighet att utveckla genom momentet.

\section{Hur tar sig lärande för hållbar utveckling uttryck i Yrkeslärarprogrammet?}

De projekt som studenterna planerar och presenterar har givetvis kursuppgiften och gruppens sammansättning som utgångspunkt. Därmed finns en given styrning avseende vissa aspekter: yrkesutbildningens policydokument i form av programmål och ämnesmål, yrkesutbildningens struktur, samt hållbarhetsbegreppet i relation till de yrkesämnen och yrkesprogram som är representerade i respektive studentgrupp. Samtliga projekt betonar betydelsen av elevernas lärande och medvetenhet om hållbar utveckling. De tre perspektiven ekologisk, ekonomisk och social hållbarhet synliggörs med olika framtoning och med skilda tolkningar. Studenterna förhåller sig mer eller mindre detaljerat till policydokument som läroplan, programmål och ämnesplaner. I vissa fall sker detta genom att ordinarie undervisningsinnehåll organiseras med fokus på temat hållbar utveckling inom ramen för kurs, ämne eller ämnesövergripande. Det innebär att den didaktiska vad-frågan anpassas för att också kunna behandla hållbarhetsaspekter. I andra fall har studenterna valt ett tema som relateras till läroplanen och då alltså till ett mer övergripande område.

Studenterna beskriver i sina presentationer exempel på utmaningar med de planerade projekten. En utmaning är att projektet ska beröra och motivera eleverna för att lära sig om hållbar utveckling: "Att motivera elever till klimatsmart tänkande och agerande, även ur ett framtidsperspektiv". Studenterna kommenterar i flera fall att elevernas attityd utgör förutsättningar för ett framgångsrikt projekt. Utmaningar som beskrivs är: "Att få eleverna att skaffa sig ett förhållningssätt så att de tar ansvar", "Medvetna om att de kan påverka miljön utifrån val de gör", "Medvetna om att de har ett globalt ansvar". En annan utmaning 
som beskrivs är att engagera andra lärare och planera för ämnesintegrerade projekt, vilket kan illustreras med följande citat: "Få med alla lärare (så många som möjligt)".

I tabellen nedan finns de 47 grupparbetena kategoriserade och tematiserade. Tabellen visar att studenternas förslag på elevprojekt omfattar tre typer av organisation av kunskapsinnehåll. Dessa är (1) yrkeskunnande som relateras till lärande för hållbar utveckling, (2) lärande för hållbar utveckling som inslag i yrkesutbildning, samt (3) lärande för hållbar utveckling som ett ämnes-, programeller skolövergripande innehåll. Dessa teman synliggörs genom den vänstra kolumnen. Vår analys av presentationsunderlagen visar också att tre undervisningsformer förekommer: (A) eleverna lär sig om hållbar utveckling, (B) eleverna lär sig om hållbar utveckling och genomför en konkret uppgift, samt (C) eleverna lär sig om hållbar utveckling och genomför ett projekt för att påverka andra. Dessa återfinns i tabellens översta rad.

Tabell 1. Tematisering av studenternas planerade projekt.

\begin{tabular}{|c|c|c|c|}
\hline & $\begin{array}{l}\text { (A) Eleverna lär sig om } \\
\text { hallbar utveckling }\end{array}$ & $\begin{array}{l}\text { (B) Eleverna lär sig om hållbar } \\
\text { utveckling och genomför en konkret } \\
\text { uppgift }\end{array}$ & $\begin{array}{l}\text { (C) Eleverna lär sig om håll- } \\
\text { bar utveckling och genomför } \\
\text { ett projekt för att påverka } \\
\text { andra }\end{array}$ \\
\hline $\begin{array}{l}\text { (1) Yrkes- } \\
\text { kunnande } \\
\text { som relateras } \\
\text { till lärande } \\
\text { för hållbar } \\
\text { utveckling }\end{array}$ & $\begin{array}{l}\text { Eco-driving: ett moment i } \\
\text { Fordons- och transport- } \\
\text { programmet } \\
\text { Hållbar utveckling, från } \\
\text { bomullsplanta till jeans: } \\
\text { ett projekt i Hantverks- } \\
\text { programmet } \\
\text { En Facebooksida om HU } \\
\text { för elever i Restaurang- } \\
\text { och livsmedelsprogram- } \\
\text { met } \\
\text { Palmoljan - är det mitt } \\
\text { problem? En temadag för } \\
\text { hela skolan }\end{array}$ & $\begin{array}{l}\text { Ett undervisningsupplägg med } \\
\text { HU-perspektiv för elever i } \\
\text { Hantverksprogrammet } \\
\text { Minska elevernas ekologiska } \\
\text { fotavtryck: ett projekt i El- och } \\
\text { energiprogrammet } \\
\text { Ett projekt om hållbar utveckl- } \\
\text { ing för elever i Livsmedelspro- } \\
\text { grammet } \\
\text { Hållbar utveckling i El- och } \\
\text { energiprogrammet } \\
\text { Inred ett hotellrum: ett moment } \\
\text { om HU i Hotell- och turism- } \\
\text { programmet } \\
\text { Hållbar utveckling: ett moment } \\
\text { på Fordons- och transport- } \\
\text { programmet } \\
\text { Integrering av hållbar utveck- } \\
\text { ling i El- och energiprogrammet }\end{array}$ & $\begin{array}{l}\text { Hållbar utveckling: mat- } \\
\text { kasse för äldre } \\
\text { Hållbar turism: ett projekt } \\
\text { för elever i Hotell- och } \\
\text { turismprogrammet } \\
\text { Temavecka om HU för } \\
\text { Naturbruksprogrammet } \\
\text { Ett kundpass för frisör- } \\
\text { elever med hållbar ut- } \\
\text { veckling i fokus } \\
\text { Evenemang Fairtrade: ett } \\
\text { arbete med HU i Handels- } \\
\text { programmet }\end{array}$ \\
\hline
\end{tabular}


Susanne Gustavsson, Ingrid Henning Loeb \& Charlotta Kvarnemo

\begin{tabular}{|c|c|c|c|}
\hline & & $\begin{array}{l}\text { Gamle Mursten: HU i Bygg- och } \\
\text { anläggningsprogrammet. }\end{array}$ & \\
\hline $\begin{array}{l}\text { (2) Lärande } \\
\text { för hållbar } \\
\text { utveckling } \\
\text { som inslag i } \\
\text { yrkesutbild- } \\
\text { ning }\end{array}$ & $\begin{array}{l}\text { Uppgift om hållbar ut- } \\
\text { veckling i Naturbruks- } \\
\text { programmets } \\
\text { NV-inriktning } \\
\text { Temadagar om HU för } \\
\text { elever i Restaurang- och } \\
\text { livsmedelsprogrammet } \\
\text { Temadag Hållbart byg- } \\
\text { gande: HU för elever i } \\
\text { Byggprogrammet och El- } \\
\text { och Energiprogrammet } \\
\text { En temadag för hela sko- } \\
\text { lan om hållbar utveckling } \\
\text { Hållbar utveckling för } \\
\text { elever i Restaurang- och } \\
\text { livsmedelsprogrammet } \\
\text { Tidsmaskinen: en spelidé } \\
\text { om hållbar utveckling för } \\
\text { elever i yrkesprogram }\end{array}$ & $\begin{array}{l}\text { Temavecka för Hantverks- } \\
\text { programmet om hållbar ut- } \\
\text { veckling } \\
\text { En temadag om Hållbar ut- } \\
\text { veckling i Naturbruksprogram- } \\
\text { met } \\
\text { Hållbar utveckling: Hur påver- } \\
\text { kar sexturismen den ekologisk, } \\
\text { sociala och den ekonomiska } \\
\text { hållbarheten? En ämnesövergri- } \\
\text { pande temadag i Hotell- och } \\
\text { turismprogrammet } \\
\text { Kan "Ekofrukost" bidra till värl- } \\
\text { dens hållbarhet? } \\
\text { Temaarbete för elever i } \\
\text { Handels- och administrations- } \\
\text { programmet } \\
\text { Biologisk mångfald och palm- } \\
\text { olja: ett moment i Naturbruks- } \\
\text { programmet } \\
\text { En blogg för frisörelever om } \\
\text { hållbar utveckling, material och } \\
\text { produkter } \\
\text { Ett programövergripande pro- } \\
\text { jekt om HU (fem yrkesprogram) }\end{array}$ & $\begin{array}{l}\text { Hållbar utveckling och } \\
\text { hälsa: Ett moment för ele- } \\
\text { ver i Vård- och omsorgs- } \\
\text { programmet och Barn- } \\
\text { och fritidsprogrammet } \\
\text { Planering av klimatsmart } \\
\text { mat i ett äldreboende } \\
\text { (Vård- och omsorgs- } \\
\text { programmet) }\end{array}$ \\
\hline $\begin{array}{l}\text { (3) Lärande } \\
\text { för hållbar } \\
\text { utveckling } \\
\text { som ett gene- } \\
\text { rellt ämnes-, } \\
\text { program-el- } \\
\text { ler skolöver- } \\
\text { gripande pro- } \\
\text { jekt. }\end{array}$ & $\begin{array}{l}\text { Temadag för hela skolan: } \\
\text { är DU klimatsmart? } \\
\text { Från ek till köksstol: } \\
\text { samverkan om hållbar ut- } \\
\text { veckling i fyra yrkespro- } \\
\text { gram } \\
\text { Socker: ett ämnesövergri- } \\
\text { pande projekt för elever i } \\
\text { Barn- och fritids- } \\
\text { programmet } \\
\text { Projektgrupp } 6 \\
\text { Ett rollspel om HU för } \\
\text { elever i olika yrkes- } \\
\text { program }\end{array}$ & $\begin{array}{l}\text { Ung företagsamhet och hållbar } \\
\text { handel: ett projekt för elever } \\
\text { Handelsprogrammet } \\
\text { En dag för hållbar utveckling } \\
\text { (hela skolan) } \\
\text { Meatfree Mondays: ett projekt } \\
\text { för elever i Vård- och omsorgs- } \\
\text { programmet och Barn- och } \\
\text { fritidsprogrammet } \\
\text { Hälsopedagogik vt 14:1 } \\
\text { (Ett moment för elever på Vård- } \\
\text { och omsorgsprogrammet samt } \\
\text { Barn- och Fritidsprogrammet) } \\
\text { Temavecka på Bygg- och }\end{array}$ & $\begin{array}{l}\text { Uppdrag studentskiva } \\
\text { (Samarbete mellan Han- } \\
\text { dels- och administrations- } \\
\text { programmet och } \\
\text { Restaurang- och } \\
\text { livsmedelsprogrammet) } \\
\text { Hållbar utveckling i } \\
\text { Fordons- och transport- } \\
\text { programmet }\end{array}$ \\
\hline
\end{tabular}


Lärande för hållbar utveckling i yrkeslärarutbildning

\begin{tabular}{|l|l|l|l|}
\hline $\begin{array}{l}\text { Eko Bazaar: ett samarbete } \\
\text { mellan programmen på } \\
\text { "Gröna skolan" med } \\
\text { temat hållbar utveckling }\end{array}$ & $\begin{array}{l}\text { anläggningsprogrammet } \\
\text { Om produkter och miljö: en } \\
\text { temadag om hållbar utveckling } \\
\text { på "Framtidsakademin" }\end{array}$ & \\
& $\begin{array}{l}\text { Miljökalendern: ett ämnesöver- } \\
\text { gripande arbete för elever i } \\
\text { gymnasiesärskolan }\end{array}$ & \\
\hline
\end{tabular}

Projekt där yrkeskunnande relateras till lärande för hållbar utveckling (1) har en tydlig och naturlig förankring i ett yrkes arbetsuppgifter och förväntade kompetens. Projektet kan direkt kopplas till vad eleverna ska lära sig, till exempel om sparsam körning som blivande chaufför. ${ }^{2}$ I dessa fall är det planerade projektets vad-fråga given och studenterna har i högre grad fokuserat på hur-frågan. Lärande för hållbar utveckling som ett inslag i yrkesprogrammet (2), innebär att projektet har en mer allmän programinriktning. Studenterna förhåller sig till hållbarhetsaspekter inom en bransch eller ett yrkesområde utan att direkt relatera till ett specifikt yrkeskunnande. Det tredje typen av innehåll är lärande för hållbar utveckling som ett generellt ämnes-, program- eller skolövergripande projekt (3), som har för avsikt att bidra till mer generell kunskap och medvetenhet om hållbar utveckling. I denna innehållskategori använder studenterna sina yrkesämneskunskaper i projekt som avser att påverka elevers attityder, levnadsstil och val. Ett exempel på ett sådant elevprojekt är ett uppdrag att arrangera en studentfest.

De planerade projekten beskriver tre olika typer av elevaktiviteter. I en typ av projekt lär sig elever om hållbar utveckling $(\mathrm{A})_{\iota}$ vilket innebär att lärare tar ansvar för att förmedla ett innehåll om hållbar utveckling via exempelvis presentationer, filmer, studiebesök eller ett experiment. Det finns en plan för hur innehållet ska gestaltas i undervisningen; vad elever ska komma i kontakt med för innehåll och därmed ges möjlighet att lära sig. Projekten där elevaktiviteten består av att lära sig om hållbar utveckling och genomföra en eller flera konkreta uppgifter (B) genomförs både i form av presentationer eller annan form av gestaltning av ett innehåll samt elevaktiva handlingar. En typ av uppgift är att eleverna samlar information om ett valt område och planerar för spridning av informationen. En annan typ av uppgift innebär att eleverna samlar information som används i ett särskilt sammanhang, eller jobbar med en uppgift, som till exempel att inreda ett hotellrum. De konkreta uppgifterna är knutna till ett yrkeskunnande, ett yrkesprogram eller av mer generell karaktär. Dessa elevuppgifter utgör i vissa fall en grund för bedömning och betygsättning. Den tredje typen av projekt, där elever lär sig om hållbar utveckling och genomför ett projekt för att påverka andra (C), innebär att elever är aktiva med olika typer av uppgifter för 
att kommunicera med eller agera i relation till en vald målgrupp. Målgruppen kan vara elever på samma skola eller en målgrupp utanför skolan.

\section{Diskussion av resultat}

De elevprojekt om lärande för hållbar utveckling som studenterna planerar och presenterar skiljer sig åt både avseende det innehåll som fokuseras, dvs. didaktikens vad-fråga, och de undervisningsformer som eftersträvas - didaktikens hurfråga. Variationen är given via den mångfald av yrkesämnen och programtillhörighet som är representerad i respektive studentgrupp. Innehållsfrågan varierar mellan att vara knuten direkt till yrkeskunnande eller till en mer allmän, samhällsorienterande kunskap. En förklaring till gruppuppgifternas innehållsliga skillnader är sammansättningen av studenter i respektive grupp. En annan förklaring kan vara studenternas olika kontextuella erfarenheter av gymnasieskolors verksamhet. De studenter som studerar på Yrkeslärarprogrammet har eller får en lokal erfarenhet av yrkesutbildning knuten till en anställning som obehörig lärare eller genom sin verksamhetsförlagda del av utbildningen (VFU). Skolans storlek, organisation, program- eller utbildningsutbud, men också lärarstudenternas lokala kunskap avgör troligen vilka möjligheter de ser i sitt bidrag till lärande för hållbar utveckling. Detta kan ses som en begränsning, men också en utgångspunkt för vidare diskussioner i studentgruppen.

I likhet med i Borgs m.fl. studie (2014) domineras projektredovisningarna av miljöperspektivet. Vissa projektredovisningar betonar dock de tre perspektiven och ger exempel på hur de är en del av det planerade projektet. Projektpresentationerna visar vidare att studenterna ofta planerar för ämnesintegrerade projekt. Ämnesintegrering kan ske mellan olika yrkesämnen eller mellan yrkesämnen och gymnasiegemensamma ämnen. Ämnesintegrering förefaller vara naturligt för studenterna, medan de samtidigt i sina presentationer under rubriken "Utmaningar" poängterar att det kan vara svårt att arrangera ämnesövergripande undervisning. Här finns problematiseringar som grundar sig i att den målstyrda gymnasieutbildningen å ena sidan är starkt fokuserad på det nödvändiga innehållet och elevers måluppfyllelse i respektive kurs. $\AA$ andra sidan är begreppet hållbar utveckling inte ämnesknutet utan har snarare sin plats i alla ämnen $i$ ett gymnasieprogram. Begreppets generella karaktär kan till och med kräva ämnesintegrering.

När det gäller didaktikens hur-fråga visar resultatet att studenter använder en variation av undervisningsformer där elevaktiviteten är mer eller mindre styrd av lärare. Vidare finns skillnader i karaktären av de aktiviteter som elever planeras att genomföra. Bland de arbetsformer som lyfts fram $i$ andra studier för hållbar utveckling finns exempel på projekt som syftar till att påverka elevers personliga ställningstagande (Boeve de Pauw m.fl., 2007; Wals, 2011). Vissa projekt 
i vår studie har ett primärt fokus på att utveckla elevers ansvar som samhällsmedborgare i mer allmän mening och hänvisar då till läroplanen.

De projekt som planeras kan i vissa fall beskrivas som transformativa till sin karaktär (Holmberg m.fl., 2012; Lotz-Sisitka m.fl., 2015; Sterling, 2009; Wals, 2011). Oavsett undervisningsform eftersträvar elevprojekten på olika sätt förändring av kunskap eller snarare att kunskapen riktas mot ett hållbarhetsperspektiv och mot att förändra attityder och värderingar (Christie m.fl, 2015; Mezirow, 1997, 2009). I de fall där elever ska påverka andra blir det transformativa perspektivet troligen mer genomgripande genom att eleverna görs till aktörer för att förändra. Få projekt nämner elevers delaktighet och inflytande. Detta kan ha sin grund i vad som efterfrågas, dvs. hur uppgiften är formulerad. Men det ger också information om att delaktighet och inflytande inte är centrala aspekter i yrkeslärarstudenternas planering av undervisning.

\section{Hur värderar studenterna sitt lärande under kursen?}

Kursen gavs första gången hösten 2013. Sedan dess har sammanlagt 255 studenter genomfört kursen där detta moment ingår. Data i tabell 2 nedan har genererats från nio kursutvärderingar, vilka genomförs i slutet av kursens avslutande campusdag. I genomsnitt har 82 procent av det totala antalet studenter gjort kursutvärderingen (spridning 56-94 \%).

Tre frågor i utvärderingen handlar om det studerade momentet. Nedan representeras de av A, B och C i tabellernas kolumner. Resultaten visar andel studenter som uppgivit " $i$ hög grad" eller "i mycket hög grad" (dvs. som svarade 4 eller 5 på frågan, där skalan var 1-5, och 5 högst).

A: I vilken grad har du uppnått kursmålet Genomföra ett arbete inom hållbar utveckling relaterat till det egna yrkesområdet?

B: I vilken grad har du uppnått kursmålet Förstå och kritisk granska begreppet hållbar utveckling och dess användning inom samhället och skolan?

C: I vilken mån har arbetet med och examinationen av uppgift 5 varit ett lärtillfälle för dig? (före ht 2016)

Tabell 2. Resultat av kursutvärdering avseende moment om lärande för hållbar utveckling ht 2013-vt 2016.

\begin{tabular}{|l|c|c|c|c|c|}
\hline Termin: & $\begin{array}{c}\text { Antal } \\
\text { studenter }\end{array}$ & $\begin{array}{c}\text { Andel som gjort } \\
\text { kursutvärderingen }\end{array}$ & A & B & C \\
\hline Ht 2013 & 36 & $88 \%$ & $66 \%$ & $65 \%$ & $50 \%$ \\
\hline Vt 2014 & 25 & $76 \%$ & $69 \%$ & $89 \%$ & $84 \%$ \\
\hline
\end{tabular}


Susanne Gustavsson, Ingrid Henning Loeb \& Charlotta Kvarnemo

\begin{tabular}{|l|c|c|c|c|c|}
\hline Ht 2014 & 30 & $80 \%$ & $96 \%$ & $100 \%$ & $88 \%$ \\
\hline Vt 2015 & 20 & $85 \%$ & $100 \%$ & $94 \%$ & $76 \%$ \\
\hline Ht 2015 & 30 & $56 \%$ & $88 \%$ & $88 \%$ & $71 \%$ \\
\hline Vt 2016 & 19 & $94 \%$ & $89 \%$ & $84 \%$ & $75 \%$ \\
\hline & Summa: $\mathbf{1 6 0}$ & & $\mathbf{8 5} \%$ & $\mathbf{8 7} \%$ & $\mathbf{7 4} \%$ \\
\hline
\end{tabular}

Efter vårterminen (vt) 2016 genomförde kursledaren och läraren som ansvarar för momentet en genomlysning (Henning Loeb \& Kvarnemo, 2016). Syftet var att få en överblick hur studenterna värderade momentet samt att få ett underlag för att förbättra delar av momentet. Vid genomlysningen ansåg vi att svaret på fråga C inte var tillfredställande. Vi hade också genom uppföljande gruppdiskussioner fått kunskap om att en del studenter uttryckte stress vid redovisningen, eller att man inte lyssnade så aktivt på de andras redovisningar, för att man satt och funderade på sin egen presentation. Med inspiration från aktionsforskning (Rönnerman \& Salo, 2017), ändrades därför introduktionen av momentet och samtalet om vad de andra gruppernas presentationer och upplägg kunde innefatta för lärande. Höstterminen 2016 ändrades även utvärderingsfråga C till: "Vi tror och hoppas att de avslutande presentationerna är inspirerande, vad det gäller innehåll och idéer om pedagogik för hållbar utveckling. I vilken mån har arbetet med och examinationen av uppgift 5 varit ett lärtillfälle för dig?"

Som framgår av resultaten i kolumn $\mathrm{C}$ i tabell 3 , innebar denna förändring förbättrade omdömen, jämfört med kolumn $\mathrm{C}$ i tabell 2.

Tabell 3. Resultat av kursutvärdering avseende moment om lärande för hållbar utveckling ht 2016-ht 2017.

\begin{tabular}{|l|c|c|c|c|c|}
\hline Termin: & $\begin{array}{c}\text { Antal } \\
\text { studenter }\end{array}$ & $\begin{array}{c}\text { Andel som gjort } \\
\text { kursutvärderingen }\end{array}$ & A & B & C \\
\hline Ht 2016 & 36 & $83 \%$ & $90 \%$ & $97 \%$ & $90 \%$ \\
\hline Vt 2017 & 21 & $80 \%$ & $88 \%$ & $82 \%$ & $83 \%$ \\
\hline Ht 2017 & 38 & $92 \%$ & $85 \%$ & $88 \%$ & $77 \%$ \\
\hline & Summa: 95 & & $\mathbf{8 8 \%}$ & $\mathbf{8 9} \%$ & $\mathbf{8 3} \%$ \\
\hline
\end{tabular}




\section{Diskussion av resultat}

Sammantaget visar resultaten att merparten av studenterna anser att de i hög grad eller mycket hög grad uppnått kursmålet att genomföra ett arbete inom hållbar utveckling relaterat till det egna yrkesområdet (A). Resultaten av omdömena på frågan om i vilken grad de uppnått kursmålet att förstå och kritisk granska begreppet hållbar utveckling och dess användning inom samhället och skolan (B) är likartade. Den tredje frågan, som fokuserar på studentens lärande (C), har oftast något lägre resultat, även om svaren på denna fråga också måste ses som godtagbara. Vid samtliga tillfällen utom de två första framkommer att minst 70 procent anser att arbetet med och examinationen av uppgiften i hög grad eller $\mathrm{i}$ mycket hög grad utgjort ett lärtillfälle.

Utvärderingsresultaten efter den genomlysning som genomfördes efter vt 2016 visar marginella förändringar avseende resultat av fråga $\mathrm{A}$ och fråga $\mathrm{B}$, vilket visar att studenterna inte har varit mer positiva över lag efter vt 2016. Däremot ser vi en tendens till en höjning av resultaten från fråga $C$. Det är därför troligt att denna höjning beror på två saker: 1) Att vi ändrade den muntliga introduktionen vid redovisningstillfället och uppmuntrade studenterna till att inte bara fokusera på sin egen redovisning utan att se alla redovisningarna som ett lärtillfälle. Vi betonade särskilt vikten av att lyssna på och engagera sig i de andra gruppernas redovisningar, för att på så vis få en bredare insikt om hur uppgiften kan tillämpas i olika undervisningsprogram. 2) Att vi formulerade om frågan i kursutvärderingen, med avsikt att hjälpa studenterna att identifiera denna möjlighet. Dessa åtgärder tillsammans fick alltså bedömningen att i medeltal stiga från 74 procent till 83 procent. Förhoppningsvis reflekterar denna höjning i resultatet en bättre upplevelse av lärandet, och ett större perspektiv på hur en uppgift som denna kan utformas i olika yrkesprogram.

Med hjälp av enkätsvaren kan vi dock inte dra någon slutsats om det som i policy och forskning återkommer avseende en ambition om ett transformativt lärande. I vilken grad eller hur de enskilda studenterna genomgått ett i grunden förändrat synsätt och hur deras kunskap och det lärande som de värderar högt avseende detta specifika moment inom utbildningen kan omvandlas till en konkret handlingsaspekt finns utifrån detta empiriska underlag ingen möjlighet att veta. Detta gäller även de från forskare framskrivna påpekandena om vikten av att lärande för hållbar utveckling ska generera ett kritiskt förhållningssätt. Att momentets innehåll och form med grupparbete och presentationer i helklass har värderats högt ger inte heller någon ledtråd om hur den enskilde studentens kritiska tänkande har förändrats.

Likväl finns det skäl att dra slutsatsen att momentet innefattar en förändrad förståelse för hållbar utveckling och lärande för hållbar utveckling samt att mo- 
mentet överlag värderas som mycket relevant av studenterna. I analysen av resultaten i genomlysningen (Henning Loeb \& Kvarnemo, 2016) jämfördes studenterna värdering av momentet med hållbar utveckling med andra delar i kursen samt med värderingen av kursen som helhet (tabell 4).

Tabell 4. Resultat av kursutvärdering för kursens samtliga moment.

\begin{tabular}{|l|c|c|c|c|c|c|}
\hline Termin: & A & B & C & D & E & F \\
\hline Ht 2013 & $66 \%$ & $65 \%$ & $50 \%$ & $75 \%$ & $75 \%$ & $84 \%$ \\
\hline Vt 2014 & $69 \%$ & $89 \%$ & $84 \%$ & $84 \%$ & $74 \%$ & $84 \%$ \\
\hline Ht 2014 & $96 \%$ & $100 \%$ & $88 \%$ & $100 \%$ & $92 \%$ & $100 \%$ \\
\hline Vt 2015 & $100 \%$ & $94 \%$ & $76 \%$ & $100 \%$ & $100 \%$ & $94 \%$ \\
\hline Ht 2015 & $88 \%$ & $88 \%$ & $71 \%$ & $77 \%$ & $78 \%$ & $100 \%$ \\
\hline Vt 2016 & $89 \%$ & $84 \%$ & $75 \%$ & $83 \%$ & $84 \%$ & $94 \%$ \\
\hline Genomsnitt: & $\mathbf{8 5} \%$ & $\mathbf{8 7} \%$ & $\mathbf{7 4} \%$ & $\mathbf{8 6} \%$ & $\mathbf{8 4} \%$ & $\mathbf{9 3} \%$ \\
\hline
\end{tabular}

I tabellen är kolumn D resultatet på frågan "I vilken grad har du uppnått kursmålet att redogöra för några teorier och perspektiv om skolutveckling?", E är resultatet på frågan "I vilken grad har du uppnått kursmålet att utarbeta och presentera en plan för ett tänkt utvecklingsprojekt med en frågeställning och några verktyg för att kunna följa och dokumentera?", och F är resultatet på frågan "Har kursen i sin helhet varit relevant i relation till läraryrket?". För denna fråga var skalan 4-gradig. Procenttalet i kolumn F grundar sig på sammanslagningen av svaren "Som helhet mycket relevant" samt "Det mesta relevant". Med denna tabell där värderingar av två andra moment synliggörs, och där relevansen av kursen som helhet belyses, kan vi sätta momentet om hållbar utveckling i sitt sammanhang och konstatera att det är ett uppskattat moment i en kurs som anses ha hög relevans för det framtida läraryrket.

\section{Avslutande diskussion och sammanfattande slutsatser}

Yrkeslärare representerar många olika ämnesområden. I den svenska gymnasieskolan finns idag över 200 yrkesämnen och dessa ämnen består också oftast av flera kurser. Yrkeslärare är också ofta en perifer lärargrupp i gymnasieskolan, knutna till de specifika program som de undervisar i, utifrån sin yrkeskompetens. Samtidigt har de, genom sin erfarenhet av arbetslivet och sin kunskap om hur branscher måste förhålla sig till miljölagstiftning och frågor om hållbar utveckling, oftast en gedigen kunskapsbas som knyter an till samhällsfrågor. Yrkes- 
lärare är således viktiga aktörer, med möjligheter att påverka sina elever, men även möjligheter att bidra med kunskap till andra lärarkategorier i en gymnasieskola eller en annan utbildningsverksamhet.

Resultaten i denna studie visar en stor mångfald av didaktiska möjligheter. Här finns en rik representation av innehållsliga idéer kring lärande om hållbar utveckling som ger olika infallsvinklar på hur didaktikens vad-fråga kan omsättas, dels genom ämnesövergripande undervisning, dels genom yrkesspecifik undervisning. Resultaten ger också många olika förslag på undervisningsupplägg och ge möjligheter för elevaktivitet och kritisk reflektion. Uppgiften som lärarstudenterna ska ta sig an har också en fråga om hur samtliga tre perspektiv av hållbar utveckling kan vara en del av det tänkta projektet. På så sätt skapas möjligheter för lärarstudenterna att diskutera hållbar utveckling på ett sätt som möjliggör en mer komplex förståelse än den som framkom av resultaten i Borgs m.fl. studie (2014), där det ekologiska perspektivet dominerade lärarnas tankar om undervisning om hållbar utveckling. Även om vi inte kan säga något om kopplingen mellan det studenterna gör på utbildningen och deras framtida lärargärning är vår slutsats att lärarstudenter som under sin utbildning får samarbeta kring ett projekt om lärande för hållbar utveckling, och som får ta del av andras projektidéer, har en stor potential att erövra de synsätt som finns representerade hos lärarna i Björneloos studie (2007). Resultaten av analysen av studentprojekten i vår studie visar många aspekter av lärande för hållbar utveckling som en del av ett större sammanhang, och upplägg där elevers delaktighet och handlingskompetens är en given del av undervisningsinnehållet.

En diskussion om i vilken grad eller på vilket sätt som arbetet med kursmomentet innebär ett transformativt lärande hade krävt ett annat empiriskt underlag. De resultat som erhållits genom studentenkäterna om hur studenterna värderar det lärande och den kunskap som de erhållit genom momentet tolkar vi som att arbetet med och examinationen av uppgiften i hög grad eller i mycket hög grad levt upp till studenternas förväntningar, och ses som relevant för dem i deras framtida lärargärning.

\section{Slutnoter}

1 För kursplan, se Yrkeslärarprogrammet vid Göteborgs universitet, kurs LYK80G.

2 Understruken text i detta avsnitt indikerar länkar i artikelns digitala version till studenternas skriftliga redovisningar av sina projekt. 


\section{Om författarna}

Susanne Gustavsson är universitetslektor i pedagogik vid Institutionen för pedagogik och specialpedagogik, Göteborgs universitet, och arbetar huvudsakligen med yrkeslärarutbildningen och rektorsprogrammet. Forskningsområde är yrkesutbildningens undervisningspraktik och yrkeslärande i skola och på arbetsplats samt skolutveckling och företrädesvis praktiknära studier och projekt.

Ingrid Henning Loeb är docent vid Institutionen för pedagogik, kommunikation och lärande vid Göteborgs universitet. Hennes forskning rör undervisning och lärande i gymnasieskolans och vuxenutbildningens yrkesutbildningar. Hon har varit programledare för Yrkeslärarprogrammet vid Göteborgs universitet och är kursledare för kursen Utvecklingsarbete och aktionsforskning för yrkeslärare, där utbildningsmomentet som är i fokus i artikeln ingår.

Charlotta Kvarnemo är professor i zoologi vid Institutionen för biologi och miljövetenskap, Göteborgs universitet. Hon har ansvarat för momentet om hållbar utveckling på kursen Utvecklingsarbete och aktionsforskning för yrkeslärare sedan hösten 2015, med syfte att få yrkeslärarstudenterna att reflektera över begreppet och utveckla kunskap om hur man integrerar hållbar utveckling i undervisningen. I sin dagliga gärning forskar hon på evolution av djurs beteenden, kopplat till reproduktion (ungvård, partnerval, osv.). 


\section{Referenser}

Björneloo, I. (2007). Innebörder av hållbar utveckling: En studie av lärares utsagor om undervisning. Doktorsavhandling. Göteborg: Göteborgs universitet.

Boeve de Pauw, J., Gericke, N., Olsson, D. \& Berglund, T. (2015). The effectiveness of education for sustainable development. Sustainability, 7(11), 15693-15717.

Borg, C., Gericke, N., Höglund, H. \& Bergman, E. (2014). Subject-and experiencebound differences in teachers' conceptual understanding of sustainable development. Environmental Education Research, 20(4), 526-551.

Christie, M., Carey, M., Robertson, A. \& Grainger, P. (2015). Putting transformative learning theory into practice. Australian Journal of Adult Learning, 55(1), 930 .

Garrison, J., Östman, L. \& Håkansson, M. (2014). The creative use of companion values in environmental education and education for sustainable development: Exploring the educative moment. Environmental Education Research, 21(2), 183-204.

Graneheim, U. \& Lundman, B. (2004). Qualitative content analysis in nursing research: Concepts, procedures and measures to achieve trustworthiness. Nurse Education Today, 24, 105-112.

Henning Loeb, I. \& Kvarnemo, C. (2016, nov-dec). Enabling action-oriented and transformative learning for sustainability in vocational teacher education. Example from The University of Gothenburg, Sweden. Paper presented at AARE Conference, Melbourne.

Holmberg, J., Lundqvist, U., Svanström, M., Gröndahl F. \& Arehag, M. (2012). The university and transformation towards sustainability: The strategy used at Chalmers University of Technology. International Journal of Sustainability in Higher Education, 13(3), 219-231.

Lenglet, F., Zinaida, F. \& Yoko, M. (2010). ESD promises and challenges: Increasing its relevance. Global Environment Research, 14(2), 93-100.

Lotz-Sisitka, H., Wals, A., Kronlid, D. \& McGarry. (2015). Transformative, transgressive social learning: Rethinking higher education pedagogy in times of systemic global dysfunction. Current Opinion in Environmental Sustainability, 16, 73-80.

Mezirow, J. (1997). Transformative learning: Theory to practice. New Directions for Adult and Continuing Education, 74, 5-12.

Mezirow, J. (2009). Transformative learning theory. I J. Mezirow \& E.W. Taylor (Red.), Transformative learning in practice: Insights from community, workplace, and higher education (s. 18-32). San Francisco: Jossey-Bass.

Mogensen, F. \& Schnack, K. (2010). The action competence approach and the 'new' discourses of education for sustainable development, competence and quality criteria. Environmental Education Research, 16(1), 59-74. 
Olsson, D., Gericke, N. \& Chang Rundgren, S. (2016). The effect of implementation of education for sustainable development in Swedish compulsory schools-assessing pupils' sustainability consciousness. Environmental Education Research, 22(2), 176-202.

Rönnerman, K. \& Salo, P. (2017). Action research within the tradition of Nordic countries. I L. Rowell, C. Bruce, J.M. Shosh \& M. Riel (Red.), The Palgrave International Handbook of Action Research (s. 455-469). New York: Palgrave Macmillan US.

SFS 1992:1434. Lag (2005:1208). Högskolelag. Stockholm: Utbildningsdepartementet.

SFS 1993:100. Ändrad: t.o.m. SFS 2018:1503. Högskoleförordning. Bilaga 2. Stockholm: Utbildningsdepartementet.

Sterling, S. (2009). Sustainable education. I D. Gray, L. Colucci-Gray \& E. Camino (Red.), Science, society and sustainability: Education and empowerment for an uncertain world (s. 105-118). New York: Routledge.

Sterling, S. (2010a). Learning for resilience, or the resilient learner? Towards a necessary reconciliation in a paradigm of sustainable education. Environmental Education Research, 16(5-6), 511-528.

Sterling, S. (2010b). Living in the earth towards an education for our time. Journal of Education for Sustainable Development, 4(2), 213-218.

Sund, P. \& Wickman P-O. (2011). Socialization content in schools and education for sustainable development - I. A study of teachers' selective traditions. Environmental Education Research, 17(5), 599-624.

Sundbaum, K. (Red.) (2008). Utmaningen: Forskare om en hållbar mänsklighet. Stockholm: Vetenskapsrådet.

Thomas, I. (2009). Critical thinking, transformative learning, sustainable education, and problem-based learning in universities. Journal of Transformative Education, 7(3), 245-264.

UNESCO. (2014). Global Action Programme. Hämtad 31 augusti 2018 från https://en.unesco.org/gap

Wals, A. (2011). Initiative for transformative sustainability education at Wageningen University, The Netherlands. Journal of Education for Sustainable Development, 5(2), 251-255.

Warner, B. \& Elser, M. (2015). How do sustainable schools integrate sustainability education? An assessment of certified sustainable K-12 schools in the United States. The Journal of Environmental Education, 46(1), 1-22.

WCED (World Commission on Environment and Development). (1987). Our common future. London: Oxford University Press.

Öhman, M. \& Öhman, J. (2012). Harmoni eller konflikt? En fallstudie av meningsinnehållet i utbildning för hållbar utveckling. Nordic Studies in Science Education, 8(1), 59-72. 